\title{
EfFects of Weed Species Competition on the Growth of Young Coffee Plants ${ }^{1}$
}

\author{
Efeitos da Competição de Plantas Daninhas sobre o Crescimento de Plantas Jovens de Café
}

\author{
RONCHI, C.P. ${ }^{2}$ e SILVA. A.A. ${ }^{3}$
}

\begin{abstract}
The effects of competition of seven weed species on the growth of coffee plants were evaluated under greenhouse conditions. Thirty days after coffee seedling transplantation into $12 \mathrm{~L}$ pots with soil level area of $6.5 \mathrm{dm}^{2}$, weeds were transplanted into or sown in those pots, at densities of $0,1,2,3,4$ and 5 plants per pot. Competition or weedy periods from weed transplantation or emergence to plant harvesting, at weed pre-flowering stage, were: 77 days - Bidens pilosa, 98 days - Brachiaria decumbens, 180 days - Commelina diffusa, 82 days Leonurus sibiricus, 68 days - Nicandra physaloides, 148 days - Richardia brasiliensis and 133 days - Sida rhombifolia. Coffee plant height, stem diameter, leaf number and shoot dry matter were determined. Effects of competition by N. physaloides and S. rhombifolia against coffee plants were among the lowest, since only a slight decrease in all the characteristics evaluated in coffee plants was observed. The other weed species caused severe decrease in growth, mainly with increasing weed plant densities. Competition degree was found to depend on weed species and density.
\end{abstract}

Keywords: density, Coffea arabica, competition, weedy period.

RESUMO - Este trabalho teve como objetivo avaliar os efeitos da competição de sete espécies de plantas daninhas sobre o crescimento de plantas de café, cultivadas em casa de vegetação. Aos 30 dias após o transplantio das mudas de café, em vasos contendo 12 L de substrato e com área de 6,5 $\mathrm{dm}^{2}$ na superficie do solo, fez-se o transplantio e/ou a semeadura das espécies daninhas nesses vasos, em seis densidades (0, 1, 2, 3, 4 e 5 plantas por vaso). Os períodos de convivência, desde o transplantio ou emergência das plantas daninhas até a colheita das plantas, quando do florescimento das plantas daninhas, foram de 77 dias - Bidens pilosa, 180 dias Commelina diffusa, 82 dias - Leonurus sibiricus, 68 dias - Nicandra physaloides, 148 dias - Richardia brasiliensis e 133 dias - Sida rhombifolia. Foram avaliados a altura de plantas, o diâmetro do caule, o número de folhas e a massa seca da parte aérea das plantas de café. Os efeitos da competição de $\mathbf{N}$. physaloides $e \mathbf{S}$. rhombifolia sobre as plantas de café foram os menores comparados aos causados pelas demais espécies de plantas daninhas, uma vez que apenas leves decréscimos - em todas as características avaliadas - no cafeeiro foram observados. As demais espécies de plantas daninhas causaram severa redução no crescimento do cafeeiro, principalmente com o incremento da densidade delas. O grau de interferência variou com a espécie e com a densidade das plantas daninhas.

Palavras-chave: densidade, Coffea arabica, competição, período de convivência.

Recebido para publicação em 22.11.2005 e na forma revisada em 4.8.2006.

2 Pesquisador do Instituto Capixaba de Pesquisa - Incaper, Assistência Técnica e Extensão Rural, Rod BR 101 Norte, km 151, Caixa Postal 62, 29900-970 Linhares-ES, Tel: (+55) 27-3371-5177; Fax: (+55) 27-3371-4942, <pagotto@incaper.es.gov.br>. ${ }^{3}$ Professor do Departamento de Fitotecnia, Universidade Federal de Viçosa, 36570-000 Viçosa-MG, Tel: (+55) 31-3899-2617, <aasilva@ufv.br>. 


\section{INTRODUCTION}

Competition (which represents the negative effect of plant interaction) is the most studied type of interference between plants (Radosevich et al., 1996). Competition is a biological interaction between at least two plants for limited resources (manly light, water and nutrients) (McNaughton \& Wolf, 1973). Resource limitations can be caused by unavailability, poor supply, or proximity to neighbouring plants, which ultimately can aggravate an already insufficient resource or create a deficiency where ample resource was available for a single individual (Radosevich et al., 1996). Actually, competition among weeds and crops affects both types of plants; nevertheless, weeds almost always have a deleterious effect on crops (Pitelli, 1985).

In addition to these concepts, knowing the factors that affect weed competition degree and their quantification is very important in interference studies. Such information will allow growers to intervene and alter competition balance, helping the crop to obtain the resources it needs (Blanco \& Oliveira, 1978). The degree of competition can be measured as the percentage of economic crop yield reduction induced by the weeds (Pitelli, 1985). Weedy, or critical competition, period and weed density are very important among the several factors affecting competition degree. The former addresses the time period in the crop life cycle in which weed competition occurs and during which weeds should be controlled to prevent yield losses (Blanco \& Oliveira 1978; Pitelli, 1985). The latter, representing the number of plants per unit of area, is also important in competition studies because of the relationship among crop yield, number of individuals, and resources available in a particular area (Blanco, 1972; Radosevich et al., 1996; Radosevich, 1987).

Coffee plantations, especially Coffea arabica L., are the most important crop in Brazil because of their high economic value and employment generating capacity (Embrapa, 2004). In addition, Brazil ranks first in world coffee production and export. A cultivated area of 2.337 million hectares with 5.387 billion coffee plants and a production of 2.148 billion tons have been estimated for 2004/2005
(Conab, 2004). Coffee is a perennial crop grown in rows and may be productive up to 30 years. As a result of weed competition, coffee yield and quality are seriously decreased and weed control is one of the major cultural operations entailing high cost. Different crop yield losses due to weed competition have been observed, such as 77\% (Blanco et al., 1982), 55\% (Oliveira et al., 1979), 65\% (Eshetu, 2001), 52\% (Pereira \& Jones, 1954), 28\% (Merino et al., 1996) and 24\% (Moraima, et al., 2000). In addition to yield losses, several other harmful effects of weed competition on this crop are discussed elsewhere (Friessleben et al., 1991; Toledo et al., 1996; Njoroge, 1994; Ronchi et al., 2001; Silva \& Ronchi, 2003), including weeds as an alternative host to the coffee strain Xilella fastidiosa, which causes coffee leaf scorch (Leite Júnior \& Nunes, 2003; Lopes et al., 2003) and possesses a greater nutrient competitive potential than the coffee plants (Gallo et al., 1958; Ronchi et al., 2003).

Weed competition critical periods in coffee plantations have been determined under different coffee production conditions and locations. In Brazil, such period was shown to last from October to March (Oliveira et al., 1979; Blanco et al, 1982) and in Venezuela, from May to September (Moraima et al., 2000). In both locations and also in India (Pereira \& Jones, 1954), such critical periods comprise the rainy season, coinciding with crop fructification. On the other hand, a critical period of weed competition occurring during dry season (from November to April) was reported in Cuba (Friessleben et al., 1991) and El Salvador (Merino et al., 1996). Although substantial data are available on weed critical competition for this crop (at the reproductive stage) little is known about weed density, which is an important factor also affecting competition degree or intensity. Moreover, just after transplanting in the field, young coffee plants seem to be highly sensitive to weed competition since weed control in the coffee rows is an agronomical practice usually employed by growers (Ronchi et al., 2001; Silva e Ronchi, 2004). Nevertheless, the effects of weed competition on young coffee plants have been scarcely studied (Dias et al., 2004).

Several methods have been developed to study competition among different species of 
plants, each constituting a bioassay in that the response of a species is used to describe the interference of the other. The additive method is perhaps the most common approach used to study weed-crop relationships (Radosevich, 1987; Cousens, 1991; Radosevich et al., 1996). In the additive method, two (or more) plant species (the crop and the weed) are grown together. The density of one species, e.g., the crop, is almost always kept constant, while the density of the other is varied. The species whose density is not changed acts as a comparative indicator for the aggressiveness and competitiveness of the other species. The objective of this study was to use the additive method to determine the competition effects of several weed species on the growth of coffee plants. We hypothesized that the degree of weed competition against young coffee plants depends on weed species and densities.

\section{MATERIALS AND METHODS}

\section{General}

The experiment was conducted in a greenhouse in Viçosa $\left(20^{\circ} 45^{\prime} \mathrm{S}, 42^{\circ} 55^{\prime} \mathrm{W}\right.$; 650 asl), south-eastern Brazil. Plants of Coffea arabica L. cv. Red Catuaí, with five leaf pairs were transplanted in $12 \mathrm{~L}$ pots filled with a mixture of soil and organic matter $(3.5: 1, \mathrm{v} / \mathrm{v})$. The soil was a yellowish Red Podzolic, 51\% clay, $\mathrm{pH} 4.9$, with an organic matter content of $2.95 \%$, and fertilized with $1.0 \mathrm{~kg} \mathrm{~m}^{-3}$ of $\mathrm{P}_{2} \mathrm{O}_{5}$ and $3.6 \mathrm{~kg} \mathrm{~m}^{-3}$ of dolomitic limestone. Fifteen and 60 days after transplanting, $3.0 \mathrm{~g} \mathrm{~N}$ were applied to each pot. Plants were irrigated daily with a automatic sprinkle system to maintain pot capacity and to prevent competition for water.

\section{Treatments and data collection}

Six weed species (Table 1) commonly found in Brasilian coffee plantations (particularly Bidens pilosa, Commelina decumbens and Leonurus sibiricus; Rochi et al., 2001) were grown separately in each pot, containing one coffee plant. Each weed species was established at six densities $(0,1,2,3,4$ and 5 plants per pot-six treatments), with four replicates. Pots were distributed in the experimental area in a completely randomised pattern. Each experimental plot was constituted by one pot, in which the soil surface area was $0.065 \mathrm{~m}^{2}$. Thus, the weed density range established in the pots relates to the density in the fields aproximately from zero up to 75 plants per square meter. Thirty days after the coffee plants were transplanted, seed weeds (except the seedlings of Commelina diffusa, which were obtained from a stem segment) were sowed by hand directly in the pot and the densities were established by thinning them out, after weed species emergence. The weedy periods (Table 1) for each species constituted the periods between weed emergence (or transplanting for C. diffusa) and pre-flowering or flowering stage, when the experiments were discontinued. This stage was chosen because nutrient absorption and accumulation (hence, competition) show their maximum levels when plants are about to enter their reproductive phase (Singh \& Singh, 1938). At that time, coffee plant height,

Table 1 - Weed species and weedy periods between them and coffee plants

\begin{tabular}{|c|c|c|c|}
\hline \multicolumn{3}{|c|}{ Weed species } & Weedy periods ${ }^{2}$ \\
\hline Scientific names & Common names & Code $^{1 /}$ & (days) \\
\hline Bidens pilosa & beggar's ticks; cobber's pegs & BIDPI & 77 \\
\hline Brachiaria decumbens & brachiaria, signal grass & BRADC & 98 \\
\hline Commelina diffusa & dayflower, hairy wandering jew & COMDI & 180 \\
\hline Leonurus sibiricus & lion's tail; Chinese motherwort & LECSI & 82 \\
\hline Nicandra physaloides & appe-of-Peru; shoo-fly & NICPH & 68 \\
\hline Richardia brasiliensis & Brazilian pusley, Brazil pusley & SIDRH & 148 \\
\hline Sida rhombifolia & anowleaf; paddy's lucerne & RCHBR & 133 \\
\hline
\end{tabular}

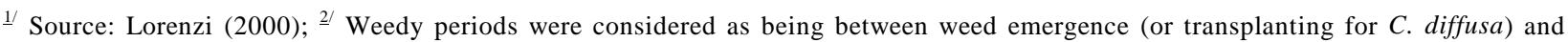
pre-flowering or flowering stage. 
steam diameter (5 $\mathrm{cm}$ above ground) and leaf number were determined. Both weed and coffee plant shoots were harvested above soil level and oven-dried for $72 \mathrm{~h}$, at $70{ }^{\circ} \mathrm{C}$ to determine shoot dry matter.

\section{Statistical analyses}

Data fitness for analysis of variance was accomplished by graphic analysis of the residues, including the Hartley test to check for error homogeneity (Neter et al., 1990). Coffee plant height, stem diameter, leaf number and shoot dry matter of both coffee plant and weeds were submitted to ANOVA and then to regression analysis. Thus, it was fitted to data significant models using weed species densities as the independent variable. Although linear models $\left(\mathrm{Y}=\beta_{0}-\beta_{1} \mathrm{X}\right)$ were used, negative exponential models $\left(\mathrm{Y}=\beta_{0} \cdot \mathrm{e}^{-\beta 1 \mathrm{X}}\right)$ were preferentially tested since they best represent the decrease in plant yield or growth with increasing weed density (Cousens et al., 1984; Aldrich, 1987; Radosevich, 1987). Correlations (Pearson's parametric method) of coffee plant height, stem diameter, leaf number and shoot dry matter with shoot dry matter of several weed species, at density of only one plant per pot, were tested using the $F$-test, at $P<0.01$. All the statistical analyses were performed using the SAEG System (SAEG, 1997).

\section{RESULTS}

\section{Coffee stem diameter}

No significant effect $(P>0.05)$ was observed from increasing densities of Brachiaria decumbens, Commelina diffusa, Nicandra physaloides and Sida rhombifolia on the stem diameter of coffee plants, grown in the same pot with coffee plants for 98, 180, 68 and 133 days, respectively (Table 2 ). In contrast, as Bidens pilosa and Richardia brasiliensis densities increased, coffee stem diameter decreased. Such a decrease was also observed for Leonurus sibiricus competition, but crop stem diameter decrease was exponential (Table 2). Among these weed species, B. pilosa decreased coffee stem diameter the most. From the regression equation shown in Table 2 , it was possible to estimate a stem diameter reduction of $29 \%$ after a weedy period of 77 days, with five plants of $B$. pilosa per pot, as compared to the weed-free crop treatment. Large differences between the weed species were found for coffee plant diameter (and also plant height, leaf number and dry matter) when weed species density was zero (data not shown). This occurred because the growth period duration differed between the weed species. Four replicates of zero weed densities were established for each species.

\section{Coffee plant height and leaf number}

Only B. pilosa and C. diffusa caused a decrease in coffee plant height, showing a linear effect $(P<0.01)$ as weed densities increased (Table 2). Among all the evaluated weeds, only $N$. physaloides and S. rhombifolia did not significantly $(P>0.05)$ promote a decrease in leaf number (Table 2). The strongest reduction of leaf number was caused by $C$. diffusa competition: based on equation in Table 2 , for the relationship between leaf number of coffee plants and C. diffusa density, a reduction of $88 \%$ was estimated when comparing coffee plants without competition to competition under five plants of $C$. diffusa.

\section{Shoot dry matter}

Besides the significant $(P<0.01)$ negative exponential effect of $C$. diffusa density on coffee shoot dry matter (Table 2), leaf abscission contributed to the low levels observed for that characteristic. N. physaloides and S. rhombifolia were the species whose increasing density in the pots did not significantly $(P>0.05)$ decrease coffee shoot dry matter (Table 2). Nevertheless, shoot dry mass of those weeds increased exponentially $(P<0.01)$ as their densities increased, reaching the maximum density value of five plants per pot (Table 3). On the other hand, there was a significant effect of $L$. sibiricus and $R$. brasiliensis densities on the reduction of coffee plant dry matter (Table 2), though weed dry matter did not increase as its density (Table 3). Overall, these results explain why no significant $(P>0.05)$ linear correlation was found between shoot dry mass of the coffee plants and of N. physaloides, $S$. rhombifolia, L. sibiricus and $R$. brasiliensis (Table 4). 
Table 2 - Stem diameter (STD), plant height (PLH), leaf number (LEN) and shoot dry matter (SDM) of coffee plants as a function of weed densities (X)

\begin{tabular}{|c|c|c|c|}
\hline Weed species & Variables ${ }^{1 /}$ & Equations & $r^{2 / 2}$ \\
\hline \multirow{4}{*}{ Bidens pilosa } & STD & $\hat{Y}=7.963-0.459^{* *} X$ & $0,87 * *$ \\
\hline & PLH & $\hat{\mathrm{Y}}=44.082-2.000 * * \mathrm{X}$ & $0,80 * *$ \\
\hline & LEN & $\hat{\mathrm{Y}}=43.238-4.929 * * \mathrm{X}$ & $0,89 * *$ \\
\hline & SDM & $\hat{\mathrm{Y}}=28.864 \mathrm{e}^{-0.202 * * \mathrm{X}}$ & $0,95^{* *}$ \\
\hline \multirow{3}{*}{ Brachiaria decumbens } & STD & $\hat{\mathrm{Y}}=\overline{\mathrm{Y}}=7.2$ & - \\
\hline & PLH & $\hat{Y}=\bar{Y}=36.3$ & - \\
\hline & SDM & $\hat{Y}=29.218-7.292 * * X+1.061 * X^{2}$ & $0,66^{*}$ \\
\hline \multirow{4}{*}{ Commelina diffusa } & STD & $\hat{\mathrm{Y}}=\overline{\mathrm{Y}}=8.8$ & - \\
\hline & PLH & $\hat{Y}=48.786-1.539 * X$ & $0,71 *$ \\
\hline & LEN & $\hat{Y}=77.183 \mathrm{e}^{-0.422 * * \mathrm{X}}$ & $0,89 * *$ \\
\hline & SDM & $\hat{\mathrm{Y}}=53.236 \mathrm{e}^{-0.254 * * \mathrm{X}}$ & $0,83^{*}$ \\
\hline \multirow{4}{*}{ Leonurus sibiricus } & STD & $\hat{\mathrm{Y}}=5.407+2.086 \mathrm{e}^{-1.307 * * \mathrm{X}}$ & $0,57 *$ \\
\hline & PLH & $\hat{\mathrm{Y}}=\overline{\mathrm{Y}}=39.1$ & - \\
\hline & LEN & $\begin{array}{l}\hat{\mathrm{Y}}=25.681+21.824 * * \mathrm{e}^{-3.239 * \mathrm{X}} \\
\\
\end{array}$ & $0,95^{* *}$ \\
\hline & SDM & $\hat{Y}=24.327-2.241 * X$ & $0,35^{*}$ \\
\hline \multirow{4}{*}{ Nicandra physaloides } & STD & $\hat{\mathrm{Y}}=\overline{\mathrm{Y}}=6.5$ & - \\
\hline & PLH & $\hat{Y}=\bar{Y}=42.1$ & - \\
\hline & LEN & $\hat{Y}=\bar{Y}=37.1$ & - \\
\hline & SDM & $\hat{\mathrm{Y}}=\overline{\mathrm{Y}}=23.1$ & - \\
\hline \multirow{4}{*}{ Richardia brasiliensis } & STD & $\hat{Y}=8.252-0.379^{*} X$ & $0,61 *$ \\
\hline & PLH & $\hat{\mathrm{Y}}=\overline{\mathrm{Y}}=40.0$ & - \\
\hline & LEN & $\hat{Y}=48.034-4.243 * X$ & $0,50 *$ \\
\hline & SDM & $\hat{\mathrm{Y}}=38.627 \mathrm{e}^{-0.189 * * \mathrm{X}}$ & $0,65^{*}$ \\
\hline \multirow{4}{*}{ Sida rhombifolia } & STD & $\hat{\mathrm{Y}}=\overline{\mathrm{Y}}=6.3$ & - \\
\hline & PLH & $\hat{\mathrm{Y}}=\overline{\mathrm{Y}}=40.0$ & - \\
\hline & LEN & $\hat{\mathrm{Y}}=\overline{\mathrm{Y}}=33.2$ & - \\
\hline & SDM & $\hat{\mathrm{Y}}=\overline{\mathrm{Y}}=21.4$ & - \\
\hline
\end{tabular}

*, ** represent the significance of the $F$-test at $P<0.05$ and $P<0.01$, respectively. ${ }^{1}$ STD, mm; PLH, cm; SDM, g.

Table 3 - Regression models fitted to statistically significant weed shoot dry matter using weed density (X) as independent variable

\begin{tabular}{|c|c|c|}
\hline Species & Equations & $r^{2}$ \\
\hline Bidens pilosa & $\hat{Y}=240.752\left(1-e^{-0.482 * * X}\right)$ & $0,93 * *$ \\
\hline Brachiaria decumbens & $\hat{Y}=427.353+192.366 * X-25.53 * X^{2}$ & $0,88^{*}$ \\
\hline Leonurus sibiricus & $\hat{\mathrm{Y}}=\overline{\mathrm{Y}}=162.3$ & - \\
\hline Nicandra physaloides & $\hat{\mathrm{Y}}=229.110\left(1-\mathrm{e}^{-0.914 * * \mathrm{X}}\right)$ & $0,90 * *$ \\
\hline Richardia brasiliensis & $\hat{\mathrm{Y}}=\overline{\mathrm{Y}}=93.9$ & - \\
\hline Sida rhombifolia & $\hat{\mathrm{Y}}=158.968\left(1-\mathrm{e}^{-0.502 * * \mathrm{X}}\right)$ & $0,89 * *$ \\
\hline
\end{tabular}

*, ** represent the significance of the $F$-test at $P<0.05$ and $\mathrm{P}<0.01$, respectively. 
Table 4 - Simple linear correlation between stem diameter (STD), plant height (PLH), leaf number (LEN) and shoot dry matter (SDM) of coffee plants and shoot dry matter of several weed species, at the density of only one plant per pot

\begin{tabular}{|l|c|c|c|c|}
\hline \multirow{2}{*}{ Species } & \multicolumn{4}{|c|}{ Variables } \\
\cline { 2 - 5 } & STD & PLH & LEN & SDM \\
\hline Bidens pilosa & $-0.60^{* *}$ & $-0.46^{* *}$ & $-0.66^{* *}$ & $-0.70^{* *}$ \\
\hline Brachiaria decumbens & $0.60^{* *}$ & 0.13 & - & 0.07 \\
\hline Leonurus sibiricus & 0.12 & 0.15 & 0.12 & 0.09 \\
\hline Nicandra physaloides & -0.14 & -0.15 & 0.03 & -0.03 \\
\hline Richardia brasiliensis & -0.01 & -0.22 & -0.23 & -0.18 \\
\hline Sida rhombifolia & -0.20 & -0.20 & -0.28 & -0.35 \\
\hline
\end{tabular}

** represents the significance of the $F$-test at $P<0.01$. " $n$ " $=44$.

Shoot dry matter of the coffee plants was exponentially reduced $(P<0.01)$ with increasing B. pilosa density (Table 2), with the opposite occurring to shoot dry matter of the latter (Table 3). This result produced a significant $(P<0.01)$ and negative linear correlation $(\mathrm{r}=-0.70)$ between coffee and B. pilosa shoot dry matters (Table 4). Taking into account Table 2 equation and the densities of zero and five plants per pot, it was coffee shoot dry mass reductions due to weed presence could be estimated. These values were 46, 61, 64 and $72 \%$ due to competition for L. sibiricus (during 82 days), $R$. brasiliensis (148 days), B. pilosa (77 days) and C. diffusa (180 days), respectively.

Unexpectedly, data relative to shoot dry mass of the coffee plants as a function of $B$. decumbens density fitted to a statistical model was different from that observed (linear) for the other species. When fitted to a square model: initially, shoot dry mass accumulation decreased as weed density increased, reaching a minimal value (16.7 g) at $B$. decumbens density of 3.44 plants per pot (estimated value), and finally with shoot dry mass rising again (Table 2). This was probably due to the fact that $B$. decumbens shoot dry mater slightly decreased at densities greater than 3.8 plants per pot (Table 3).

\section{DISCUSSION}

The additive method herein applied to study weed-crop relationships simulates a situation in which the crop is exposed to several levels of weed infestation. This method relates the weed infestation levels to crop yield reduction and can assist coffee growers in deciding whether weed control is economical (Radosevich, 1987). Moreover, the method allows the evaluation of the competitive potential of different weed species, indicating the most aggressive ones at a specific density in a given crop.

The harmful effects of weed competition on coffee plant growth or weed competition degree varied greatly depending on both the weed species and their density. N. physaloides and S. rhombifolia had little or no effect on the growth of coffee plants, even at the highest density employed in these experiments. On the other hand, B. pilosa, C. diffusa, L. sibiricus and $R$. brasiliensis markedly reduced the growth of coffee plants, as indicated by stem diameter, plant height, leaf number and shoot dry matter. Moreover, this reduction was linear or exponential with weed density increase. Indeed, C. diffusa (and C. benghalensis) followed by $B$. pilosa are weeds widely dispersed in Brazilian coffee fields (Blanco et al., 1982; Ronchi et al., 2001). In Cuba, Friessleben et al. (1991) reported that weed competition imposed to two-or three-year-old fieldgrown Coffea arabica, at the critical period of weed competition (during crop fructification), significantly reduced stem and crown diameter, plant height, number and length of plagiotropic branches, node formation on primary branches and coffee yield. Moreover, stem diameter (which was reduced by $22 \%$ ) was found to be the best indicator of weed competition for coffee plants not older than three years (Friessleben et al., 1991). Oliveira et al. (2002) reported that competition of Commelina spp. led to a reduction in leaf number, plant height and stem diameter of $C$. arabica, after this weed had been grown at several densities during 150 days following coffee transplanting into pots.

Adverse weed effects on coffee growth were brought about probably through competition mainly for essential nutrients (Gallo et al., 1958; Njoroge, 1994) and light (Blanco et al., 1982; Castro \& Garcia, 1996), since soil moisture was almost constantly available. In this study, B. decumbens, B. pilosa and L. sibiricus probably imposed the strongest 
competition for light since they quickly developed simultaneously in leaf area and height (showing a dense canopy), factors that allow weeds to be better light competitors (Walker et al., 1988).

Despite the direct effect of competition (for light and nutrients) on coffee leaf number, other factors could have contributed that strongly reduced leaf number in coffee plants under C. diffusa interference, such as the attack of Cercospora coffeicola, whose symptoms were evident on coffee leaves at the end of its weedy period. According to Zambolim et al. (1997), water and nutritional stresses predispose coffee plants to severe attack from that pathogen, leading to other symptoms, such as leaf shedding. Therefore, one may suppose that young coffee plants under C. diffusa competition were more sensitive to C. coffeicola attack; hence, this was an indirect negative effect of weed interference in coffee plants. In addition, the long weedy period (six months) of $C$. diffusa could have favoured coffee leaf number reduction. It is likely that the crop had been too long under either direct or indirect effects of weed competition.

Dry matter accumulation of individual plants was found to decrease with increasing weed density, so that the final dry matter production per pot was about the same, even at low or high weed densities. According to Radosevich et al. (1996), this phenomenon occurs because the amount of growth by individual plants decreases in a plastic manner as density increases: at low density, total yield per area unit was determined by fewer larger plants, while at high density, it is determined by many small ones. In this experiment, pot size probably contributed to nutrient competition due to of root growth constraint under a small soil volume. Moreover, taking into account that interference among neighbouring plants occurs after a specific weed density has been reached (Aldrich, 1987), in addition to crop-weed competition, intraspecific competition among individuals of the same weed species had certainly also occurred, mainly at higher densities.

Among the weeds studied, B. pilosa was the only species that caused a constant decrease in all the coffee plant characteristics evaluated, as density increased. Moreover, B. pilosa was the only weed whose shoot dry matter correlated significantly and negatively $(P<0.01)$ with the coffee plant parameters, including stem diameter, leaf number, plant height and shoot dry matter (Table 4). Therefore, B. pilosa stood out for possessing the highest competitive potential against coffee plants, probably due to its high nutrient uptake ability (Ronchi et al., 2003). Thus, even at low densities within the crop row, during the early growth phases (after transplantation), B. pilosa may cause an initial crop growth reduction, delaying crop establishment and the time taken by the plants to reach maturity, probably also reducing their bearing capacity.

Under the present experimental conditions, it is highly recommended controlling weeds within crop rows, especially if they occur at high densities in coffee fields, in order to prevent weed competition, probably for nutrients (Ronchi et al., 2003) and light, and hence, crop growth reduction. In this study the effect of weed competition may have been overestimated due to pot size. Although, under field conditions, soil volume restriction to root growth is probably much lower than that observed in the pots, the occurrence of common biotic (pathogen and insect attack) and abiotic (water deficit) stresses might aggravate weed competition against coffee plants. Moreover, weed densities in young field coffee plantations are usually found to be much higher than those studied here, which could lead to a high degree of competition as reported here. Although weeds possess some important agronomical characteristics (e.g. recycling nutrients from the soil profile), they should not be allowed to thrive near coffee plants because they reduce their growth. Further research on weed competition against young coffee plants under field conditions is of major importance to improve coffee crop management.

\section{LITERATURE CITED}

ALDRICH, R. J. Predicting crop yield reductions from weeds. Weed Technol., v. 1, p. 199-206, 1987.

BLANCO, H. G. A importância dos estudos ecológicos nos programas de controle das plantas daninhas. Biológico, v. 38, p. 343-350, 1972. 
BLANCO, H. G.; OLIVEIRA, D. A. Estudos dos efeitos da época de controle do mato sobre a produção de citros e a composição da flora daninha. Biológico, v. 45, p. 25-36, 1978.

BLANCO, H. G.; OLIVEIRA, D. A.; PUPO, E. I. H. Período de competição de uma comunidade natural de mato em uma cultura de café em formação. Biológico, v. 48, p. 9-20, 1982.

CASTRO, C. R. T.; GARCIA, R. Competição entre plantas com ênfase no recurso luz. Ci. Rural, v. 26, p. 167-174, 1996.

COMPANHIA NACIONAL DE ABASTECIMENTO CONAB. Previsão inicial da safra brasileira de café 2004/ 2005 e levantamento do parque cafeeiro nacional. Disponível em: <http://www.conab.gov.br/download/Safra/ Safracafe.pdf $>$. Acesso em: 29 fev. 2004.

COUSENS, R. Aspects of the design and interpretation of competition (interference) experiments. Weed Technol., v. 5, p. 664-673, 1991.

COUSENS, R.; PETERS, N. C. B.; MARSHALL, C. J. Models of yield loss-weed density relationships. Inter. Symp. Weed Biol. Ecol. System, v. 7, p. 367-374, 1984.

DIAS, G. F. S.; ALVES, P. L. C. A.; DIAS, T. C. S. Brachiaria decumbens suppresses the initial growth of Coffea arabica. Sci. Agric., v. 61, p. 579-583, 2004.

EMPRESA BRASILEIRA DE PESQUISA AGROPECUÁRIA - EMBRAPA. Café: histórico. Disponível em: <http://www.embrapa.br/cafe/historico.htm>. Acesso em: 29 fev. 2004.

ESHETU, T. Weed flora and weed control practices in coffee. In: COLLOQUE SCIENTIFIQUE

INTERNATIONAL SUR LE CAFE, 19., 2001, Trieste, Italy. Colloque... Paris: ASIC, 2001. p. 1-9.

FRIESSLEBEN, U.; POHLAN, J.; FRANKI, G. The response of Coffea arabica $\mathrm{L}$. to weed competition. Café, Cacao The, v. 35, p. 15-20, 1991.

GALLO. J. R. et al. Absorção de nutrientes pelas ervas daninhas e sua competição com o cafeeiro. Campinas: Instituto Agronômico de Campinas, 1958. 13 p. (Boletim Instituto Agronômico, 104)

LEITE JÚNIOR, R. P.; NUNES, L. M. Avanços nas pesquisas sobre Xylella fastidiosa do café no Brasil. In: ZAMBOLIM, L. (Ed.). Produção integrada de café. Viçosa, MG: Universidade Federal de Viçosa, 2003. p. $87-101,2003$.

LOPES, S. A. et al. Weeds as alternative hosts of the citrus, coffee, and plum strains of Xylella fastidiosa in Brazil. Plant Disease, v. 87, p. 544-549, 2003.
LORENZI, H. Manual de identificação e controle de plantas daninhas: plantio direto e convencional. 5.ed. Nova Odessa: Plantarum, 2000. 384 p.

McNAUGHTON, S. J.; WOLF, L. L. General Ecology. New York: Holt, Rinchart \& Winston, 1973. 710 p.

MERINO, M. C. I.; RAMIRES, A. R.; IBARRA, E. L. Study on critical periods for interspecific competition, weedscoffee. In: SIMPOSIO SOBRE CAFICULTURA LATINOAMERICANA, 17., 1996, San Salvador. Anais... Tegucigalpa: IICA, 1996. $15 \mathrm{p}$.

MORAIMA, G. S. et al. A contribution to determine critical levels of weed interference in coffee crops of Monagas state, Venezuela. Bioagro, v. 12, p. 63-70, 2000.

NETER. J.; WASSERMAN, V.; KUTNER, M. H. Applied linear statistical models: regression, analysis of variance and experimental designs. Homewood: Richard A. Irwin, 1990. $842 \mathrm{p}$.

NJOROGE, J. M. Weeds and weed control in coffee. Exp. Agric., v. 30, p. 421-429, 1994.

OLIVEIRA, A. R.; FREITAS, S. P.; VIEIRA, H. D. Efeito da competição de trapoerabas no crescimento de plantas de café (Coffea arabica) recém-transplantadas. In: CONGRESSO BRASILEIRO DA CIÊNCIA DAS PLANTAS DANINHAS 23., 2002, Gramado. Resumos... Londrina: Sociedade Brasileira da Ciência das Plantas Daninhas, Embrapa Clima Temperado, 2002. p. 461.

OLIVEIRA, J. A.; MATIELO, J. B.; CARVALHO, F. Estudo do efeito da época de controle das plantas daninhas em café. In: CONGRESSO BRASILEIRO DE PESQUISA CAFEEIRA, 7., 1979, Araxá, MG. Resumos... Rio de Janeiro: IBC, 1979. p. 360-362.

PEREIRA, H. C.; JONES, P. A. A tillage study in Kenya Coffee. Part I: the effects of tillage practices on coffee yields. Emp. J. Exp. Agric., v. 22, p. 231-240, 1954.

PITELLI, R. A. Interferência de plantas daninhas em culturas agrícolas. Inf. Agropec., v. 120, p. 16-27, 1985.

RADOSEVICH, S. R. Methods to study interactions among crops and weeds. Weed Technol., v. 1, p. 190-198, 1987.

RADOSEVICH, S. R.; HOLT, J.; GHERSA, C. Weed ecology: implication for managements. New York: John Wiley \& Sons, 1996. 589 p.

RONCHI, C. P. et al. Acúmulo de nutrientes pelo cafeeiro sob interferência de plantas daninhas. Planta Daninha, v. 21, p. 219-227, 2003.

RONCHI, C. P.; SILVA, A. A.; FERREIRA, L. R. Manejo de plantas daninhas em lavouras de café. Viçosa, MG: Suprema Gráfica \& Editora, 2001. 94 p. 
SISTEMA DE ANÁLISES ESTATÍSTICAS E GENÉTICAS - SAEG. Viçosa, MG: Fundação Arthur Bernardes, 1997. Versão 7.1

SILVA, A. A.; RONCHI, C. P. Avanços nas pesquisas sobre o controle de plantas daninhas na cultura do café. In: ZAMBOLIM, L. (Ed.). Produção integrada de café. Viçosa, MG: Universidade Federal de Viçosa, 2003. p. 103-132.

SINGH, B. N.; SINGH, L. B. Relative absorption of nutrients by weeds of arable land. Soil Sci., v. 47, p. $227-235,1938$.
TOLEDO, S. V.; MORAES, M. V.; BARROS, I. Efeito da freqüência de capinas na produção do cafeeiro. Bragantia, v. 55, p. 317-324, 1996.

WALKER, G. K.; BLACKSHAW, R. E.; DEKKER, J. Leaf area and competition for light between plant species using direct sunlight transmission. Weed Technol., v. 2, p. 159-165, 1988.

ZAMBOLIM, L. et al. Café: Coffea arabica L.; controle de doenças. In: VALE, F. X. R.; ZAMBOLIM, L. (Eds.).

Controle de doenças de plantas: grandes culturas. Viçosa, MG: Universidade Federal de Viçosa, 1997. p. 83-180. 